\title{
Cortisol in individuals with autism spectrum disorders - review
}

\section{Kortyzol u osób z zaburzeniami ze spektrum autyzmu - przegląd piśmiennictwa}

\author{
Zuzanna Lewandowska (D), Katarzyna Mazur-Melewska (DMagdalena Figlerowicz (DD \\ Department of Infectious Diseases and Child Neurology, Poznan University of Medical Sciences, Poland \\ DOl:10.20966/chn.2020.59.467
}

\section{ABSTRACT}

Cortisol is a hormone crucial for homeostasis of the human organism. Many researchers proved the role of cortisol and its normal release rhythm in healthy individuals. It led to further investigations of the abnormalities in cortisol levels in those affected by various disorders, especially with neuropsychiatric symptoms. Autism spectrum disorder is one of these conditions which have been intensively researched due to its core and secondary symptoms.

We conducted a systematic review of articles in PubMed, including papers that met the search criteria "autism" and "cortisol". After initial selection of relevant papers, we analyzed data from 56 articles. We divided data into subcategories of studies concerning cortisol diurnal profile, basal cortisol levels, Cortisol Awakening Response (CAR) and cortisol levels in reaction to certain stimuli.

Data was unequivocal, however, abnormal diurnal profile, basal level, CAR or stressor response were found in many research groups. It led to suspicion that the abnormalities of cortisol release are a widely-spread phenomenon among individuals with autism spectrum disorder. Very limited data from therapeutic interventions indicated more clinical than biological response. This systematic review should be a drive to action for further randomized clinical trial on larger, homogenous group of patients to obtain more thorough insight into the role of cortisol in autism spectrum disorder.

Key words: cortisol, autism spectrum disorder, children

\begin{abstract}
STRESZCZENIE
Kortyzol jest jednym z kluczowych hormonów dla zachowania homeostazy w organizmie człowieka, co zostało wykazane w wielu badaniach u osób zdrowych. Zbadano również prawidłowy rytm uwalniania kortyzolu. Stanowi to podstawę do dalszych badań zaburzeń wydzielania kortyzolu w różnych schorzeniach, szczególnie tych objawiających się zaburzeniami neuropsychiatrycznymi. Zaburzenia ze spektrum autyzmu stanowią jeden z najintensywniej badanych problemów zdrowotnych ze względu na objawy osiowe autyzmu, takie jak lęk czy zaburzenia spoteczne i zachowania, jak również dodatkowe objawy, takie jak zaburzenia snu czy czynnościowe przewodu pokarmowego.

Przeprowadziliśmy systematyczny przegląd piśmiennictwa w bazie PubMed, uwzględniając artykuły spełniające kryteria wyszukiwania "autism" (autyzm) i "cortisol" (kortyzol). Po pierwotnej selekcji istotnych prac, przeanalizowaliśmy 56 artykułów. Omawianie wyników podzieliliśmy na podkategorie, dotyczące profilu dobowego kortyzolu, podstawowych jego poziomów, wydzielania przy obudzeniu oraz poziomów w reakcji na konkretny bodziec.

Analizowane dane były niejednoznaczne. Zaburzenia profilu dobowego kortyzolu, podstawowego jego poziomu, wydzielania przy obudzeniu oraz poziomów w reakcji na stresor stanowity jednakże częste zjawisko wśród badanych osób z zaburzeniami ze spektrum autyzmu. Nieliczne dane dotyczące wpływu prowadzonych działań terapeutycznych wskazywały na częściej osiąganą kliniczną poprawę niż zmiany w stężeniu kortyzolu. Poniższy przegląd piśmiennictwa powinien stanowić podstawę do przeprowadzenia randomizowanych badań klinicznych na dużej, homogennej grupie, by uzyskać bardziej wnikliwe spojrzenie na rolę kortyzolu w zaburzeniach ze spektrum autyzmu. Słowa kluczowe: kortyzol, autyzm, dzieci
\end{abstract}

\section{INTRODUCTION AND AIMS}

Cortisol is one of the key hormones of human organism participating in stress response control [1], regulation of circadian sleep-wake rhythm [2], metabolism and calcium homeostasis [3] and motor learning [4]. It can also influence immune, endocrine, respiratory and cardiovascular systems and has an impact on skin and connective tissue, memory and vision [5]. The circadian rhythm of cortisol release is established at an early age of 6 months [6] and can be influenced by several factors, such as food consumption, season [7], light [8], and social factors [9].

Cortisol and its circadian rhythm is well researched in healthy children and adolescents. It is also investigated in different health conditions, especially those presenting with neuropsychiatric symptoms. Autism spectrum disor- der is a neurodevelopmental condition presenting mostly with social and communication difficulties and stereotypical behavior [10]. It is one of these disorders that are the most intensively investigated because of abnormal social skills development and anxiety symptoms [11,12]. It is even more interesting in the context of abnormal sleep pattern in many individuals [13] and functional gastrointestinal symptoms that can also be connected with abnormal cortisol release patterns [14].

The aim of this paper is to present a comprehensive systematic review of literature concerning cortisol release in individuals with autism. As the nature of hormonal abnormalities is still under investigation such a summary should serve as an s initial stage for further studies . 


\section{Materials and methods}

We performed a search in PubMed using the descriptors "autism" and "cortisol", looking for papers reported in English or in Polish published in the peer-reviewed journals with no discrimination of publication date. This resulted in 161 records. We excluded the papers concentrated on parents and biological stimulus for cortisol and included only original data. This resulted in including 56 papers in this systematic review.

In order to maintain readability we divided analyzed data into smaller subgroups such as papers concentrated on cortisol diurnal profile, basal cortisol levels, Cortisol Awakening Response [CAR] and cortisol levels in reaction to certain stimuli.

\section{Circadian rhythm of cortisol}

In healthy individuals we expect the highest levels of cortisol in the early morning hours after awakening. Normally, in the situation when an individual is not subject to any additional stressors, the cortisol level decreases throughout the day to its lowest point in the evening to early night hours [15]. High evening cortisol or flattened cortisol profile slope can be connected with continuous engagement with external stimuli serving as stressors [16]. It can lead to the abnormalities in the development and growth as well as in the behavior of affected young individual [17]. The abnormal rhythm also makes patients prone to depression and anxiety disorders [18].

The information from 23 papers concerning circadian rhythm of cortisol release is summarized in Table I [5,19-40].

In the plasma cortisol measurements, three out of five papers reported an abnormal circadian rhythm in autism spectrum disorder patients. Hill et al. reported significantly lower awakening levels of cortisol and lower levels throughout the day, with multiple peaks not observed in the control group, however, it is crucial to emphasise that the size of both groups was quite small [20].

In urinary cortisol papers Richdale et al. reported normal rhythm [24], while Priya et al. observed higher levels of cortisol [25]. However, Richdale included only high-functioning individuals and Priya examined the subgroups of high, medium and low-functioning ones, with a correlation between the cortisol level and abnormal functioning.
A normal cortisol profile was observed in two out of sixteen studies [26,27]. The common pattern was flattened diurnal cortisol slope $[26,31,33,35]$. Three papers reported higher overall cortisol $[31,34,35]$. Some researchers observed also higher evening cortisol in comparison to control group $[29,33,35,36]$. The abnormal cortisol release pattern correlated with the repetitive behaviour [29], anxiety [32] and sleep disturbances [36].

The only paper including hair cortisol levels also reported higher level of cortisol [35].

Some older research also covered the experiments with dexamethasone suppression test, which is typically used to assess adrenal glands activity. The researchers equivocally presented high percentage of non-suppressors among children with autism [37-39].

The results seem to be unequivocal, however, data come from very diverse studies. They differ in methodology of cortisol measurement, sample sizes, age and functioning of the patients.

Most of the studies were based on a relatively small group of patients, which leads to question whether their statistical analysis meets the requirements of the minimum sample size for the population. They were also usually based on the high-functioning patients, probably due to a problematic recruitment and non-compliance among low functioning individuals.

Most of the researchers used methods for acute cortisol levels measurement. Only one decided to investigate the chronic level of this hormone in hair samples. Blood cortisol was the first method used to assess its level and it is mostly seen in older papers. The limitations of the method were complicated assays, influence of the other hormones and binding proteins on the results [41] and, what is especially important in patients with autism, the influence of the blood taking as a stressor. Urine and saliva cortisol represent better free cortisol and are both non-invasive, however, urine samples might be hard to take from the low-functioning individuals, what is more, it may be problematic to obtain urine samples at the exact time, making saliva the most widely used method for cortisol measurement [42].

Nineteen out of twenty-three analyzed papers presented different extent of abnormalities in the cortisol diurnal release in children with autism, indicating that there are

Tab. I Cortisol circadian rhythm - results of studies Rytm okołodobowy kortyzolu - wyniki badań

\begin{tabular}{|c|c|c|}
\hline Research & Research group (RG) vs control group (CG) & Results \\
\hline \multicolumn{2}{|c|}{ Plasma cortisol } \\
\hline Yamazaki (1975) & $\begin{array}{c}\text { RG: 5M, 2F; no CG (compared to previously } \\
\text { studied data) }\end{array}$ & Abnormal circadian rhythm \\
\hline Hill (1977) & RG: 5M, 1F; CG: 1M, 2F & $\begin{array}{c}\text { RG: lower morning levels, relatively lower daytime } \\
\text { levels, multiple peaks }\end{array}$ \\
\hline Aihara (1989) & RG: 25M, 5F; no CG & Abnormal circadian rhythm \\
\hline Sandman (1991) & RG: 8; CG: 17 & Normal morning and evening levels \\
\hline Nir (1995) & RG: 10M; CG: 5 & No differences between RG and CG \\
\hline
\end{tabular}




\begin{tabular}{|c|c|c|}
\hline \multicolumn{3}{|c|}{ Urinary cortisol } \\
\hline Richdale (1992) & RG: 14M, 4F; CG: 16M, 3Fm & Normal rhyth \\
\hline Priya (2013) & $\begin{array}{l}\text { RG: } 36 \mathrm{M}, 9 \mathrm{~F}-15 \text { in each group: low } \\
\text { functioning, medium functioning, high } \\
\text { functioning; CG: } 36 \mathrm{M}, 9 \mathrm{~F}\end{array}$ & $\begin{array}{l}\text { Higher levels in } \mathrm{RG} \text {, correlation between abnormal } \\
\text { diurnal rhythm and low functioning }\end{array}$ \\
\hline \multicolumn{3}{|c|}{$\begin{array}{r}\text { Salivary cortisol } \\
\end{array}$} \\
\hline Corbett (2004) & RG: 12M; CG: 9M & $\begin{array}{l}\text { No significant difference, more visible difference } \\
\text { between subjects in } R G \text { than in } C G\end{array}$ \\
\hline $\begin{array}{l}\text { Marinović-Curin } \\
\text { (2008) }\end{array}$ & RG: 9M; CG: 7M & No significant difference \\
\hline Corbett (2008) & RG: 21M, 1F; CG: 19M, 3F & $\begin{array}{l}\text { Normal peak-to-trough rhythm; decrease in morning } \\
\text { sample over course of } 6 \text { days in } R G \text { vs no decrease } \\
\text { in } C G \text {; higher results in evening sample in RG; more } \\
\text { visible difference between subjects in RG than in } C G\end{array}$ \\
\hline Corbett (2009) & RG: 21M, 1F; CG: 19M, 3F & $\begin{array}{l}\text { RG: more variability, more shallow slope of diurnal } \\
\text { profile }\end{array}$ \\
\hline Kidd (2012) & RG: 26 (M:F ratio: 4:1); CG: 26 & $\begin{array}{l}\text { Higher morning cortisol in RG, no difference in } \\
\text { afternoon and evening cortisol; higher between- } \\
\text { subject differences in RG; negative correlation } \\
\text { between cortisol levels and IO }\end{array}$ \\
\hline Gabriels (2013) & $\begin{array}{l}\text { RG: } 21 \mathrm{M}-11 \text { with high repetitive behaviour } \\
\text { (RB) rate, } 10 \text { with low } \mathrm{RB} \text { rate; no CG }\end{array}$ & $\begin{array}{l}\text { RG children with high RB rate presented with } 36 \% \\
\text { lower diurnal cortisol than those with low rate; both } \\
\text { groups with the same pattern of diurnal profile }\end{array}$ \\
\hline Tordjman (2014) & RG: 36M, 19F; CG: 22M, 10F & $\begin{array}{c}\text { RG: Higher levels, flattened circadian slope, correlation } \\
\text { between cortisol levels and non-verbality, higher } \\
\text { between-subject differences }\end{array}$ \\
\hline Bitsika (2015) & RG: 150M; no CG & $\begin{array}{c}\text { RG: Higher levels, flattened circadian slope, correlation } \\
\text { between cortisol levels and non-verbality, higher } \\
\text { between-subject differences }\end{array}$ \\
\hline Tomarken (2015) & RG: 30M, 6F; CG: 23M, 4F & $\begin{array}{l}\text { Overall higher cortisol levels in RG - no difference in } \\
\text { CAR, difference in evening cortisol; } 25 \% \text { of RG had } \\
\text { flatter diurnal profile }\end{array}$ \\
\hline Shapley (2016) & RG: 39F, no CG & $15 \%$ presented abnormal diurnal profile \\
\hline Ogawa (2016) & RG: 30M, 4F; CG: 12 & Higher cortisol levels in RG \\
\hline Muscatello (2018) & RG: 57M, 7F; CG: 42M, 7F & $\begin{array}{l}\text { Abnormal diurnal slope, higher evening cortisol in RG; } \\
\text { no differences in total cortisol or at any time point }\end{array}$ \\
\hline Baker (2019) & $\begin{array}{l}\text { RG: } 15 \mathrm{M}, 14 \mathrm{~F}-13 \text { medicated for anxiety } \\
\text { and/or depression; CG: } 15 \mathrm{M}, 14 \mathrm{~F}\end{array}$ & $\begin{array}{l}\text { Reduction in cortisol in RG without medication; higher } \\
\text { cortisol before sleep was correlated with poorer sleep } \\
\text { efficiency, increased sleep onset latency, reduced total } \\
\text { sleep time (both subgroups) and increased wake after } \\
\text { sleep onset (subgroup without medication) }\end{array}$ \\
\hline \multicolumn{3}{|c|}{ Hair cortisol } \\
\hline Ogawa (2016) & RG: 30M, 4F; CG: 12 & $\begin{array}{l}\text { Higher cortisol levels in RG, positive correlation with } \\
\text { Autism Spectrum Quotient, no correlation with special } \\
\text { memory work performance }\end{array}$ \\
\hline \multicolumn{3}{|c|}{$\begin{array}{c}\text { Dexamethasone suppression test (DST) } \\
\end{array}$} \\
\hline Hoshino (1984) & $\begin{array}{l}\text { RG: } 15 \mathrm{M}, 4 \mathrm{~F} \text {; CG: healthy adults }-14 \mathrm{M}, 12 \mathrm{~F}, \\
\text { adults with schizophrenia - 9M, 10, children } \\
\text { with intellectual disability - 9M, 1F, children } \\
\text { with minimal brain dysfunction }-5 \mathrm{M}\end{array}$ & $\begin{array}{l}\text { Higher percentage of non-suppressors in DST (more } \\
\text { common in low-functioning ones) }\end{array}$ \\
\hline Jensen (1985) & RG: 9M, 4F; no CG & Majority of RG are non-suppressors in DST \\
\hline Hoshino (1987) & $\begin{array}{l}\text { RG: 19M, 3F; CG: children - 15M, 12F + } \\
\text { adults - 5M, } 1 \mathrm{~F}\end{array}$ & $\begin{array}{l}\text { Abnormal profile in some children (more common in low- } \\
\text { functioning ones); higher percentage of non-suppressors } \\
\text { in DST (more common in low-functioning ones) }\end{array}$ \\
\hline
\end{tabular}


indeed some important changes in that hormone profile. Data correlating with some axial and secondary neuropsychiatric symptoms with abnormalities in cortisol level seem to support this conclusion.

\section{Basal cortisol levels.}

Basal cortisol levels in all studies were measured in one sample of plasma, mostly in the morning sample. Table II summarizes research on basal cortisol levels [43-50].

Six out of eight papers reported some abnormalities in the cortisol levels. Three of them observed lower levels $[43,45,46]$ and one observed a higher one [47]. One of them compared cortisol level to dehydroepiandrostendione-sulphate (DHEA-S) level, showing higher ratio in patients with autism [50]. The correlation between the level of cortisol and some neuropsychiatric symptoms (irritability, stereotypy, hyperactivity) scored in Abberant Behaviour Checklist in younger children was reported by Bitsika et al. [44]

Tab. II Basal cortisol levels Podstawowe poziomy kortyzolu
The results differ between the reports. It is well-established that the basal cortisol levels can differ according to the age (especially pubertal status) and sex of patients [51]. The discrepancies in age and sex structure between the groups can lead to unequivocal results. Once again, groups were rather small and some cortisol release might have been connected with blood taking process. However, Croonenberghs et al. report is a very interesting finding in the context of neurotoxic effect of cortisol in contrast to neuroprotective influence of DHEA-S [50,52]. Elevated cortisol/DHEA-S can be connected with neuropsychiatric symptoms [53]. The parts of central nervous system especially susceptible to neurotoxicity of cortisol are hippocampus and limbic systems [54-56]. These structures are usually affected in autism spectrum disorder, what supports this observation even more [57].

\begin{tabular}{|c|c|c|}
\hline Research & Research group (RG) vs control group (CG) & Results \\
\hline Herman (1988) & RG: 5 & Lower plasma cortisol in $\mathrm{RG}$ \\
\hline $\begin{array}{l}\text { Marinović-Curin } \\
\text { (2003) }\end{array}$ & RG: 27M, 9F; CG: 19M, 8F & Lower plasma cortisol in $\mathrm{RG}$ \\
\hline Tani (2005) & RG: 14M, 6F - Asperger syndrome; CG: 7M, 3F & No differences \\
\hline $\begin{array}{l}\text { Croonenberghs } \\
(2008))\end{array}$ & RG: 18M; CG: 22M & $\begin{array}{l}\text { Higher baseline cortisol/dehydroepiandrostendione- } \\
\text { sulphate ratio in RG }\end{array}$ \\
\hline Hamza (2010) & $\begin{array}{c}\mathrm{RG}: 18 \mathrm{M} ; \mathrm{CG}: 22 \mathrm{M} \\
\mathrm{RG}: 40 \mathrm{M}, 10 \mathrm{~F} ; \mathrm{CG}: 40 \mathrm{M}, 10 \mathrm{~F}\end{array}$ & Lower plasma cortisol in $\mathrm{RG}$ \\
\hline Iwata (2011) & RG: 32M; CG: 34M & Higher plasma cortisol in $\mathrm{RG}$ \\
\hline Bitsika (2015) & RG: 150M; no CG & $\begin{array}{l}\text { Correlation between basal cortisol and Abberant } \\
\text { Behavior Checklist score in boys (irritability, } \\
\text { stereotypy, hyperactivity); no correlation in } \\
\text { adolescents }\end{array}$ \\
\hline $\begin{array}{l}\text { Bakker-Huvenaars } \\
\qquad(2018)\end{array}$ & RG: 49M; CG: 28M & No differences \\
\hline Hassan (2018) & RG: 73M; CG: 73M & Lower plasma cortisol in $\mathrm{RG}$ \\
\hline
\end{tabular}

\section{Cortisol Awakening Response}

Cortisol Awakening Response (CAR) is a well-observed phenomenon in the healthy individuals with a greater influence on the psychophysical homeostasis [58, 59]. In a normal CAR we observe cortisol increasing twice in 30 minutes after awakening [60]. It is not susceptible to age, puberty differences, sleep length and quality, or personal activity, which makes it a more stable marker of the hypothalamic-pituitary axis functioning $[8,61,62]$.

Table III summarizes the research in CAR among autism spectrum disorder patients [5, 27, 30, 63-66].

Four out of eight papers found no significant difference between autism spectrum disorder patients and the control group. Two reported no CAR or reversed CAR, with no association with Autism Diagnostic Observation Schedule $[5,66]$. One showed a correlation between CAR and anxiety [64].

\section{Reaction to stimulus}

Table IV presents the results of research on cortisol reaction to different stimuli in autism spectrum disorder [67-86]. To make it clear we divided papers into subgroups, first one with patients after positive stimulus(such as manual, physical or other intervention)and second - after negative one (such as stressor). 
Tab. III CAR

Poziom kortyzolu po wybudzeniu

\begin{tabular}{|c|c|c|}
\hline Research & Research group (RG) vs control group (CG) & Results \\
\hline Sharpley (2006) & RG: 39F, no CG & $\begin{array}{l}\text { Over } 50 \% \text { did not present with an increase from } \\
\text { waking measure to } 30 \text { minutes after }\end{array}$ \\
\hline $\begin{array}{l}\text { Marinović-Curin } \\
\text { (2008) }\end{array}$ & RG: 9M; CG: 7M & No significant difference \\
\hline Brosnan (2009) & RG: 20M; CG: 18M & Abnormal CAR (no peak after 30 minutes) \\
\hline Zinke $(2010))$ & RG: 13M, 2F; CG: 21M, 4F & No significant difference \\
\hline Gabriels (2013 & $\begin{array}{l}\text { RG: } 21 \mathrm{M}-11 \text { with high repetitive behaviour } \\
\text { (RB) rate, } 10 \text { with low } \mathrm{RB} \text { rate; no } \mathrm{CG}\end{array}$ & No significant difference \\
\hline Bitsika (2014) & RG: 32M; no CG & $\begin{array}{l}\text { Correlation between waking cortisol and self-rated } \\
\text { anxiety }\end{array}$ \\
\hline Corbett (2014) & RG: 47M; CG: 50M & No significant difference \\
\hline Sharpley (2016) & RG: 39F, no CG & $\begin{array}{l}59 \% \text { of RG had no CAR or reversed CAR, Autism } \\
\text { Diagnostic Observation Schedule not associated } \\
\text { with CAR, no influence of emotional reaction on CAR }\end{array}$ \\
\hline Sharpley (2019) & RG: 32M; no CG & $\begin{array}{l}\text { Half of RG had no CAR or reversed CAR, Autism } \\
\text { Diagnostic Observation Schedule not associated } \\
\text { with CAR, no influence of emotional reaction on CAR }\end{array}$ \\
\hline
\end{tabular}

Out of three papers with a positive stimulus, that is therapeutic intervention, in the theatre intervention no influence on cortisol was observed, however, there were clinical improvement of behaviour [69]. The horseback riding had a positive influence on cortisol levels in both the research and control group [67]. On the other hand, the dog therapy resulted in a reduced CAR, with a secondary increase after stopping the stimulus [68].

A negative stimulus was used in 19 studies. The stimulus comprised mostly of social interaction, however some papers covered different approaches (mock MRI, dental treatment, cold pressor, blood draw).

In three cases there was no difference between the research and control group [73, 78, 82]. In the remaining 17 papers, the results were once again ambiguous, however, there were some returning patterns. Three papers reported a lower cortisol level in response to social situation $[70,76,80]$. Naber et al. observed the correlation between a lower cortisol level and the intensiveness of autism core symptoms [70]. Hollocks et al. investigated the correlation between anxiety and decrease in cortisol level [76]. One paper showed that the increase of cortisol depends on self-reported irritability of the patient [77] and another one showed that anxiety and avoidance does not seem to influence the level of cortisol after social interaction [73]. 11 of them observed higher cortisol level after stressor. It was observed for social interactions, mock MRI and dental treatment, however Schupp et al. observed it only in older children. Lopata et al. observed the increase only if the child first performed social activity with a familiar, and then with an unfamiliar person - if they contacted an unfamiliar person first, there was no increase in cortisol level after secondary interaction with a familiar person [70]. Higher level of cortisol correlated also with an ab- normal behavior during the dental treatment and the intensiveness of functional gastrointestinal symptoms from lower tract [81].

What is interesting, many researchers used Trier Social Stress Test as a stressor, which is a peer interaction playground paradigm based on the social evaluation of children. In all papers, the children did not respond to that stimulus with increase of cortisol level, However, when Corbett et al. used Trier Social Stress Test - Friendly, a modification which changes the test into social interaction stressor, the peak of cortisol was observed in the research group [84]. This shows an interesting approach to what serves as a stressor for children with autism.

It is not surprising that most of the children responded not only emotionally but also biologically by cortisol increase to social stressor. Social skills disturbances are one of the key symptoms in autism and also one of the symptoms that are the most debilitating and limiting independence from caregiver in later life. There is no established treatment for social skills rather than psychological and occupational therapy, sometimes supported by pharmacotherapy of symptoms of depression and anxiety. From interventional studies, the dog therapy seemed promising as a part of social skills therapy, however, this research should be replicated on a larger group of patients [68].

\section{DISCUSSION}

The results of the already conducted research on the cortisol release and response in autism spectrum disorder patients are unequivocal due to many limitations of papers (mainly diverse research groups, different cortisol measurement methods, small number of patients included in research].

However, what can be observed, the cortisol profi- 
Tab. IV Cortisol in reaction to stimulus

Poziom kortyzolu po stymulacji na bodziec

\begin{tabular}{|c|c|c|c|}
\hline Research & $\begin{array}{l}\text { Research group (RG) vs control } \\
\text { group (CG) }\end{array}$ & Stimulus type & Results \\
\hline \multicolumn{4}{|c|}{ Positive stimulus } \\
\hline Corbett (2017) & $\begin{array}{l}\text { RG: } 17 \text { - autism with } \\
\text { intervention; } C G-13 \text { - autism } \\
\text { without intervention }\end{array}$ & $\begin{array}{l}\text { Theatre-based } \\
\text { intervention }\end{array}$ & $\begin{array}{l}\text { No influence on cortisol, clinical } \\
\text { improvement in social skills }\end{array}$ \\
\hline Viau (2010) & $\begin{array}{c}\text { RG: } 37 \mathrm{M}, 5 \mathrm{~F} \text { (34 - autism, } \\
2 \text { - Asperger syndrome, } \\
6 \text { - pervasive developmental } \\
\text { disorder-not otherwise specified) }\end{array}$ & Dog therapy & $\begin{array}{l}\text { Lower Cortisol Awakening Response (CAR) } \\
\text { after introducing dog (an increase at the } \\
\text { awakening: } 58 \% \text { before dog and } 10 \% \text { after } \\
\text { dog); raising of CAR after removing dog (an } \\
\text { increase at the awakening: } 48 \% \text { ) }\end{array}$ \\
\hline Pan (2019) & $\begin{array}{c}\text { RG: } 8 \text { (horseback riding); CG: } 8 \\
\text { (barn activity) }\end{array}$ & $\begin{array}{l}\text { Therapeutic horseback } \\
\text { riding }\end{array}$ & $\begin{array}{c}\text { ASignificant decrease of cortisol in both RG } \\
\text { and CG; no significant difference between } \\
\text { groups }\end{array}$ \\
\hline \multicolumn{4}{|c|}{ Negative stimulus } \\
\hline Naber (2006) & $\begin{array}{l}\text { RG: } 20 \text { - autism, } 14 \text { - pervasive } \\
\text { developmental disorder; CG: } 18\end{array}$ & $\begin{array}{l}\text { Strange Situation } \\
\text { Procedure }\end{array}$ & $\begin{array}{l}\text { More intensive symptoms of autism } \\
\text { connected to lower cortisol level after } \\
\text { stimulus; significant difference between } \\
\text { children with autism and CG }\end{array}$ \\
\hline Lopata (2008) & RG: 31M, 2F; no CG & $\begin{array}{l}\text { Card game session with } \\
\text { familiar or unfamiliar } \\
\text { peer }\end{array}$ & $\begin{array}{l}\text { Higher cortisol if child interacted with } \\
\text { familiar person first and unfamiliar after; no } \\
\text { difference if unfamiliar interaction was first }\end{array}$ \\
\hline Corbett (2010) & RG: 21M; CG: 24M & $\begin{array}{l}\text { Playground peer } \\
\text { interactions }\end{array}$ & $\begin{array}{c}\text { Higher cortisol levels in RG; enhanced } \\
\text { cortisol response in children playing } \\
\text { voluntarily }\end{array}$ \\
\hline Lanni (2012) & RG: 15M; CG: 15M & Trier Social Stress Test & No significant differences \\
\hline Spratt (2012) & RG: 11M, 9F; CG: 15M, 13F & $\begin{array}{l}\text { Novel environment, } \\
\text { blood draw }\end{array}$ & $\begin{array}{l}\text { Higher peak, prolonged response after blood } \\
\text { draw in RG }\end{array}$ \\
\hline Simon (2013) & RG: 19M; CG: 21M & $\begin{array}{l}\text { Peer interaction } \\
\text { playground paradigm, } \\
\text { mock MRI, Trier Social } \\
\text { Stress Test }\end{array}$ & $\begin{array}{c}\text { Higher cortisol in response to playground } \\
\text { paradigm and mock MRI, lack of response } \\
\text { to Trier Social Stress Test }\end{array}$ \\
\hline Schupp (2013) & $\begin{array}{l}\text { RG: } 26 \mathrm{M} \text { (21 - autism, } 5 \\
\text { - pervasive developmental } \\
\text { disorder-not otherwise } \\
\text { specified); CG: } 26\end{array}$ & $\begin{array}{l}\text { Peer interaction } \\
\text { playground paradigm }\end{array}$ & $\begin{array}{l}\text { Older children in RG had higher cortisol } \\
\text { levels after stimulus; younger children in } \\
\text { RG had lower cortisol levels after stimulus } \\
\text { than CG; younger children presented with } \\
\text { a decrease in cortisol level over time }\end{array}$ \\
\hline Hollocks (2014) & RG: 52M; CG: 23M & $\begin{array}{l}\text { Playground peer } \\
\text { interactions }\end{array}$ & $\begin{array}{l}\text { Higher cortisol levels in RG; less social } \\
\text { communication in individuals with higher } \\
\text { cortisol levels }\end{array}$ \\
\hline Abdulla (2015) & RG: 50, CG: 50 & Dental treatment & $\begin{array}{l}\text { Cortisol levels correlated negatively with } \\
\text { children's behaviour during dental treatment } \\
\text { in } \mathrm{RG} \text {, but not in } \mathrm{CG}\end{array}$ \\
\hline $\begin{array}{l}\text { Edmiston } \\
\text { (2015) }\end{array}$ & RG: 12; CG: 16 & $\begin{array}{l}\text { Peer interaction } \\
\text { playground paradigm }\end{array}$ & $\begin{array}{c}\text { Higher cortisol levels in RG after face- } \\
\text { to-face encounter, interaction between } \\
\text { high cortisol and decreased activation of } \\
\text { left insula and bilateral temporal parietal } \\
\text { junction }\end{array}$ \\
\hline Mikita (2015) & RG: 47M; CG: 23M & Psychosocial stress test & $\begin{array}{c}\text { Significant changes in cortisol level after } \\
\text { stressor in RG; lower cortisol in highly- } \\
\text { irritable RG patients in comparison to low- } \\
\text { irritable ones }\end{array}$ \\
\hline
\end{tabular}




\begin{tabular}{|c|c|c|c|}
\hline Corbett (2016) & RG: 34M, 6F; CG: 32M; 8F & Trier Social Stress Test & $\begin{array}{c}\text { Higher cortisol levels in RG; individuals } \\
\text { with higher cortisol levels presented with } \\
\text { stronger sensory sensitivity and enhanced } \\
\text { stress }\end{array}$ \\
\hline $\begin{array}{l}\text { Ferguson } \\
(2016)\end{array}$ & RG: $108 \mathrm{M}, 12 \mathrm{~F} ;$ no CG & Cold pressor stimulation & $\begin{array}{l}\text { Positive correlation between cortisol } \\
\text { response to stimuli and symptoms from } \\
\text { lower gastrointestinal tract, assessed } \\
\text { by The Questionnaire on Pediatric } \\
\text { Gastrointestinal Symptoms-Rome III }\end{array}$ \\
\hline $\begin{array}{l}\text { Edmiston } \\
(2016)\end{array}$ & RG: 24M, 4F; CG: 15M, 3F & Trier Social Stress Test & $\begin{array}{c}\text { Non-significant increase in RG vs significant } \\
\text { increase in } C G\end{array}$ \\
\hline $\begin{array}{l}\text { Bishop- } \\
\text { Fitzpatrick } \\
\text { (2017) }\end{array}$ & RG: 40; CG: 25 & $\begin{array}{l}\text { Social Stress Recall } \\
\text { Task }\end{array}$ & No significant differences \\
\hline Matherly (2018) & $\begin{array}{l}\text { RG1: } 15 \mathrm{M} \text { - autism; RG2: } 50 \mathrm{M}- \\
\text { Fragile X Syndrome }\end{array}$ & $\begin{array}{l}\text { Language and cognitive } \\
\text { tasks with unfamiliar } \\
\text { person }\end{array}$ & $\begin{array}{l}\text { Anxiety and avoidance had no influence on } \\
\text { cortisol levels in RG1 (patients with autism) }\end{array}$ \\
\hline Corbett (2019) & RG: 20M, 11F; CG: 18M, 7F & $\begin{array}{l}\text { Trier Social Stress Test } \\
\text { (social evaluation); } \\
\text { Trier Social Stress } \\
\text { Test Friendly (social } \\
\text { interaction) }\end{array}$ & $\begin{array}{l}\text { RG: correlation between respiratory sinus } \\
\text { arrhythmia and social interaction, but not to } \\
\text { social evaluation; CG: the opposite }\end{array}$ \\
\hline Corbett (2020) & RG: 122M, 36F; CG: 57M, 46F & Trier Social Stress Test & $\begin{array}{l}\text { RG: blunted response to stressor and } \\
\text { quicker return to normal level of cortisol }\end{array}$ \\
\hline
\end{tabular}

le and stressor response is in many cases abnormal and often correlate with neuropsychiatric symptoms of autism, both core and secondary ones. This supports the theory that cortisol has a crucial influence on early age development and that the abnormalities in its release can lead to neuropsychiatric problems [89-91]. In the animal studies high levels of corticosterone, equivalent of human cortisol, resulted in the hippocampal damage [90] which led to learning deficits in rodents [91]. It seems to make central nervous system more vulnerable to both external and internal damaging stimuli [93] and is hypothesized to be one of the factors in neurodegenerative disorders, such as Alzheimer's disease [93, 94].

There was a very limited data on whether any interventions such as psychotherapy or occupational therapy can normalize cortisol release in children with autism. It is very promising, however, that even in the lack of biological response, children seemed to benefit from those intervention by clinical mitigation of problematic behaviour.

Due to limitations of the previous research future papers should concentrate on performing large, randomized clinical trials for obtaining population results rather than data applicable only to the research group. This could lead to further understanding of the role and disturbances in cortisol release in the individuals with autism spectrum disorder.

\section{CONCLUSION}

We analyzed 56 papers concerning different aspects and different approaches to cortisol release in the patients with autism spectrum disorder. Data from analyzed papers were unequivocal, however many individuals presented with some abnormalities in diurnal profile, basal level, CAR or response to stressor. There is a very limited data concerning interventions and their influence on cortisol level, however, those already published showed more clinical than biological response to therapy. Further research should be conducted on a homogenous, large group of patients in randomized clinical trial.

\section{BIBLIOGRAPHY}

[1] McEwen B.S.: Protective and damaging effects of stress mediators. Dialogues Clin Neurosci. 2006; 8: 367-381.

[2] McEwen B.S.: What Is the Confusion With Cortisol? Chronic Stress. 2019; 3: 2470547019833647.

[3] McEwen B.S., Karatsoreos I.N.: Sleep Deprivation and Circadian Disruption: Stress, Allostasis, and Allostatic Load. Sleep Med Clin. 2015; 10: 1-10.

[4] Liston C., Cichon J.M., Jeanneteau F., et al.: Circadian glucocorticoid oscillations promote learning-dependent synapse formation and maintenance. Nature Neuroscience. 2013; 16: 698-705.

[5] Sharpley C.F., Bitsika V., Agnew L.L., et al.: Is daily replication necessary when sampling cortisol concentrations in association studies of children with autism spectrum disorder? A systematic review and discussion paper. Reviews in the Neurosciences. 2017; 28: 103-111.

[6] Onishi S., Miyazawa G., Nishimura Y., et al.: Postnatal development of circadian rhythm in serum cortisol levels in children. Pediatrics. 1983; 72: 399-404.

[7] Touitou Y., Sulon J., Bogdan A., et al.: Adrenocortical hormones, ageing and mental condition: seasonal and circadian rhythms of plasma 18-hydroxy-11-deoxycorticosterone, total and free cortisol and urinary corticosteroids. J Endocrinol. 1983; 96: 53-64.

[8] Levine M.E., Milliron A.N., Duffy L.K.: Diurnal and seasonal rhythms of melatonin, cortisol and testosterone in interior Alaska. Arctic Med Res. 1994; 53: 25-34.

[9] Aschoff J., Fatranska M., Giedke H., et al.: Human circadian rhythms in continuous darkness: entrainment by social cues. Science. 171 (3967): 213-215. 
[10] King B.H., Navot N., Bernier R., et al.: Update on diagnostic classification in autism. Curr Opin Psychiatry. 2014; 27: 105-109.

[11] van Steensel F.J.A., Bögels S.M., Perrin S.: Anxiety disorders in children and adolescents with autistic spectrum disorders: a meta-analysis. Clin Child Fam Psychol Rev. 2011; 14: 302-317.

[12] Simon D.M., Corbett B.A.: Examining associations between anxiety and cortisol in high functioning male children with autism. J Neurodevelop Disord. 2013; 5: 32

[13] Devnani P.A., Hegde A.U.: Autism and sleep disorders. J Pediatr Neurosci. 2015; 10: 304-307.

[14] Mayer E.A.: The neurobiology of stress and gastrointestinal disease. Gut. 2000; 47: 861-869.

[15] Pruessner J., Wolf 0., Hellhammer D.H., et al.: Free cortisol levels after awakening: a reliable biological marker for the assessment of adrenocortical activity. Life Sciences. 1997; 61: 2539-2549.

[16] Sapolsky R.M., Krey L., McEwen B.S.: The neuroendocrinology of stress and aging: the glucocorticoid cascade hypothesis. Endocr Rev. 1986; 7: 284-301.

[17] Chrousos G.P.: Stress and disorders of the stress system. Nat Rev Endocrinol. 2009; 5: 374-381.

[18] Schiefelbein V.L., Susman E.J.: Cortisol Levels and Longitudinal Cortisol Change as Predictors of Anxiety in Adolescents. The Journal of Early Adolescence. 2006; 26: 397-413.

[19] Yamazaki K., Saito Y., Okada F., etal.: An application of neuroendocrinological studies in autistic children and Heller's syndrome. J Autism Dev Disord. 1975:5: 323-332.

[20] Hill S.D., Wagner E.A., Shedlarski J.G., et al.: Diurnal cortisol and temperature variation of normal and autistic children. Dev Psychobiol. 1977; 10: 579-583

[21] Sandman C.A., Barron J.L., Chicz-DeMet A., et al.: Brief Report: PlasmaEndorphin and Cortisol Levels in Autistic Patients. J Autism Dev Disord. 1991; 21: 83-87.

[22] Nir I., Meir D., Zilber N., et al.: Brief report: Circadian melatonin, thyroidstimulating hormone, prolactin, and cortisol levels in serum of young adults with autism. J Autism Dev Disord. 1995; 25: 641-654.

[23] Aihara R., Hashimoto T.: [Neuroendocrinologic studies on autism]. No To Hattatsu. 1989; 21: 154-162.

[24] Richdale A.L., Prior M.: Urinary cortisol circadian rhythm in a group of high-functioning children with autism. J Autism Dev Disord. 1992; 22: 433-437.

[25] Lakshmi Priya M.D., Geetha A., Suganya V., et al.: Abnormal circadian rhythm and cortisol excretion in autistic children: a clinical study. Croat Med J. 2013; 54: 33-41.

[26] Corbett B., Mendoza S., Abdullah M., et al.: Cortisol circadian rhythms and response to stress in children with autism. Psychoneuroendocrinology. 2006; 31: 59-68.

[27] Marinović-Ćurin J., Marinović-Terzić I., Bujas-Petković Z., et al.: Slower cortisol response during ACTH stimulation test in autistic children. Eur Child Adolesc Psychiatry. 2008; 17: 39-43.

[28] Corbett B.A., Schupp C.W., Levine S., et al.: Comparing cortisol, stress, and sensory sensitivity in children with autism. Autism Res. 2009; 2 39-49.

[29] Corbett B.A., Mendoza S., Wegelin J.A., et al.: Variable cortisol circadian rhythms in children with autism and anticipatory stress. J Psychiatry Neurosci. 2008; 33: 227-234.

[30] Gabriels R.L., Agnew J.A., Pan Z., et al.: Elevated repetitive behaviors are associated with lower diurnal salivary cortisol levels in autism spectrum disorder. Biological Psychology. 2013; 93: 262-268.

[31] Kidd S.A., Corbett B.A., Granger D.A., et al.: Daytime Secretion of Salivary Cortisol and Alpha-Amylase in Preschool-Aged Children with Autism and Typically Developing Children. J Autism Dev Disord. 2012; 42: 2648-2658.

[32] Tordjman S., Anderson G.M., Kermarrec S., et al.: Altered circadian patterns of salivary cortisol in low-functioning children and adolescents with autism. Psychoneuroendocrinology. 2014; 50: 227-245.

[33] Bitsika V., Sharpley C.F., Andronicos N.M.: Hypothalamus-pituitaryadrenal axis daily fluctuation, anxiety and age interact to predict cortisol concentrations in boys with an autism spectrum disorder. Physiology \& Behavior. 2015; 138: 200-207.

[34] Tomarken A.J., Han G.T., Corbett B.A.: Temporal patterns, heterogeneity, and stability of diurnal cortisol rhythms in children with autism spectrum disorder. Psychoneuroendocrinology. 2015; 62: 217-226.

[35] Ogawa S., Lee Y.-A., Yamaguchi Y., et al.: Associations of acute and chronic stress hormones with cognitive functions in autism spectrum disorder. Neuroscience. 2017; 343: 229-239.
[36] Muscatello R.A., Corbett B.A.: Comparing the effects of age, pubertal development, and symptom profile on cortisol rhythm in children and adolescents with autism spectrum disorder: Development and Diurnal Rhythm in ASD. Autism Research. 2018: 11: 110-120.

[37] Baker E.K., Richdale A.L., Hazi A., et al.: Assessing a hyperarousal hypothesis of insomnia in adults with autism spectrum disorder. Autism Research. 2019; 12: 897-910.

[38] Hoshino Y., Yokoyama F., Watanabe M., et al.: The Diurnal Variation and Response to Dexamethasone Suppression Test of Saliva Cortisol Level in Autistic Children. Psychiatry Clin Neurosci. 1987; 41: 227-235.

[39] Jensen J.B., Realmuto G.M., Garfinkel B.D.: The Dexamethasone Suppression Test in Infantile Autism. Journal of the American Academy of Child Psychiatry. 1985; 24: 263-265.

[40] Hoshino Y., Yoshinori O., Murata S., et al.: Dexamethasone Suppression Test in Autistic Children. Psychiatry and Clinical Neurosciences. 1984; $38: 445-459$.

[41] El-Fahran N., Rees D.A., Evans C.: Measuring cortisol in serum, urine and saliva - are our assays good enough? Ann Clin Biochem. 2017; 54: 308-322.

[42] Kirschbaum C., Hellhammer D.H.: Salivary cortisol in psychoneuroendocrine research: Recent developments and applications. Psychoneuroendocrinology. 1994; 19: 313-333.

[43] Marinović-Ćurin J., Terzić J., Bujas-Petković Z., et al.: Lower Cortisol and Higher ACTH Levels in Individuals with Autism. J Autism Dev Disord. 2003; 33: 443-448.

[44] Bitsika V., Sharpley C.F., Agnew L.L., et al.: Age-related differences in the association between stereotypic behaviour and salivary cortisol in young males with an Autism Spectrum Disorder. Physiology \& Behavior. 2015; 152: 238-243.

[45] Hamza R.T., Hewedi D.H., Ismail M.A.: Basal and Adrenocorticotropic Hormone Stimulated Plasma Cortisol Levels Among Egyptian Autistic Children: Relation to Disease Severity. Ital J Pediatr. 2010; 36: 71.

[46] Hassan M.H., Desoky T., Sakhr H.M., et al.: Possible Metabolic Alterations among Autistic Male Children: Clinical and Biochemical Approaches. J Mol Neurosci. 2019; 67: 204-216.

[47] Iwata K., Matsuzaki H., Miyachi T., et al.: Investigation of the serum levels of anterior pituitary hormones in male children with autism. Mol Autism. 2011; 2: 16.

[48] Tani P., Lindberg N., Matto V., et al.: Higher plasma ACTH levels in adults with Asperger syndrome. Journal of Psychosomatic Research. 2005; 58: 533-536.

[49] Bakker-Huvenaars M.J., Greven C.U., Herpers P., et al.: Saliva oxytocin, cortisol, and testosterone levels in adolescent boys with autism spectrum disorder, oppositional defiant disorder/conduct disorder and typically developing individuals. European Neuropsychopharmacology. 2020; 30: 87-101.

[50] Croonenberghs J., Spaas K., Wauters A., et al.: Faulty serotonin - DHEA interactions in autism: results of the 5 -hydroxytryptophan challenge test. Neuro Endocrinol Lett. 2008; 29: 385-390.

[51] Hadlow N., Collier S., Wardrop R., et al.: Variation of serum cortisol with age and gender. Address: : https://www.aacb.asn.au/documents/ item/508, access: 13.02.2021.

[52] Goodyer I.M., Park R.J., Netherton C.M., et al.: Possible role of cortisol and dehydroepiandrosterone in human development and psychopathology. Br J Psychiatry. 2001; 179: 243-249.

[53] McEwen B.S.: Protection and damage from acute and chronic stress: allostasis and allostatic overload and relevance to the pathophysiology of psychiatric disorders. Ann N Y Acad Sci. 2004; 1032: 1-7.

[54] Bastianetto S., Ramassamy C., Poirier J., et al.: Dehydroepiandrosterone (DHEA) protects hippocampal cells from oxidative stress-induced damage. Brain Res Mol Brain Res. 1999 20; 66: 35-41.

[55] Diamond D.M., Branch B.J., Fleshner M., et al.: Effects of dehydroepiandrosterone sulfate and stress on hippocampal electrophysiological plasticity. Ann N Y Acad Sci. 1995; 774: 304-307.

[56] Compagnone N.A., Mellon S.H.: Dehydroepiandrosterone: a potential signalling molecule for neocortical organization during development. Proc Natl Acad Sci U S A. 1998; 95: 4678-4683.

[57] Cardounel A., Regelson W., Kalimi M.: Dehydroepiandrosterone protects hippocampal neurons against neurotoxin-induced cell death: mechanism of action. Proc Soc Exp Biol Med. 1999; 222: 145-149.

[58] Clow A., Thorn L., Evans P., et al.: The awakening cortisol response: methodological issues and significance. Stress. 2004; 7: 29-37.

[59] Fries E., Dettenborn L., Kirschbaum C.: The cortisol awakening response (CAR): facts and future directions. Int J Psychophysiol. 2009; 72: 67-73. 
[60] Brosnan M., Turner-Cobb J., Munro-Naan Z., et al.: Absence of a normal Cortisol Awakening Response (CAR) in adolescent males with Asperger Syndrome (AS). Psychoneuroendocrinology. 2009; 34: 1095-1100.

[61] Wilhelm I., Born J., Kudielka B.M., et al.: Is the cortisol awakening rise a response to awakening? Psychoneuroendocrinology. 2007; 32: 358366

[62] Rosmalen J.G.M., Oldehinkel A.J., Ormel J., et al.: Determinants of salivary cortisol levels in 10-12 year old children; a population-based study of individual differences. Psychoneuroendocrinology. 2005; 30 483-495.

[63] Zinke K., Fries E., Kliegel M., et al.: Children with high-functioning autism show a normal cortisol awakening response (CAR). Psychoneuroendocrinology. 2010; 35: 1578-1582.

[64] Bitsika V., Sharpley C.F., Sweeney J.A., et al.: HPA and SAM axis responses as correlates of self- vs parental ratings of anxiety in boys with an Autistic Disorder. 2014; 7.

[65] Corbett B.A., Swain D.M., Newsom C., et al.: Biobehavioral profiles of arousal and social motivation in autism spectrum disorders. J Child Psychol Psychiatr. 2014; 55: 924-934.

[66] Sharpley C.F., Bitsika V., Andronicos N.M., et al.: Further evidence of HPA-axis dysregulation and its correlation with depression in Autism Spectrum Disorders: Data from girls. Physiology \& Behavior. 2016; 167 110-117.

[67] Pan Z., Granger D.A., Guérin N.A. et al.: Replication Pilot Trial of Therapeutic Horseback Riding and Cortisol Collection With Children on the Autism Spectrum. Front Vet Sci. 2019; 5: 312.

[68] Viau R., Arsenault-Lapierre G., Fecteau S., et al.: Effect of service dogs on salivary cortisol secretion in autistic children. Psychoneuroendocrinology 2010; 35: 1187-1193

[69] Corbett B.A., Blain S.D., loannou S., et al.: Changes in anxiety following a randomized control trial of a theatre-based intervention for youth with autism spectrum disorder. Autism. 2017; 21: 333-343.

[70] Naber F.B.A., Swinkels S.H.N., Buitelaar J.K., et al.: Attachment in Toddlers with Autism and Other Developmental Disorders. J Autism Dev Disord. 2007; 37: 1123-1138.

[71] Lopata C., Volker M.A., Putnam S.K., et al.: Effect of Social Familiarity on Salivary Cortisol and Self-Reports of Social Anxiety and Stress in Children with High Functioning Autism Spectrum Disorders. J Autism Dev Disord. 2008; 38: 1866-1877.

[72] Corbett B.A., Schupp C.W., Simon D., et al.: Elevated cortisol during play is associated with age and social engagement in children with autism. Mol Autism. 2010; 1: 13.

[73] Lanni K.E., Schupp C.W., Simon D., et al.: Verbal ability, social stress, and anxiety in children with Autistic Disorder. Autism. 2012; 16: 123-138.

[74] Spratt E.G., Nicholas J.S., Brady K.T., et al.: Enhanced Cortisol Response to Stress in Children in Autism. J Autism Dev Disord. 2012; 42: 75-81.

[75] Schupp C.W., Simon D., Corbett B.A.: Cortisol Responsivity Differences in Children with Autism Spectrum Disorders During Free and Cooperative Play. J Autism Dev Disord. 2013; 43: 2405-2417.

[76] Hollocks M.J., Howlin P., Papadopoulos A.S., et al.: Differences in HPAaxis and heart rate responsiveness to psychosocial stress in children with autism spectrum disorders with and without co-morbid anxiety. Psychoneuroendocrinology. 2014; 46: 32-45.

[77] Mikita N., Hollocks M.J,. Papadopoulos A.S., et al.: Irritability in boys with autism spectrum disorders: an investigation of physiological reactivity. $J$ Child Psychol Psychiatr. 2015; 56: 1118-1126.
[78] Edmiston E.K., Merkle K., Corbett B.A.: Neural and cortisol responses during play with human and computer partners in children with autism. Social Cognitive and Affective Neuroscience. 2015; 10: 1074-1083.

[79] Edmiston E.K., Blain S.D., Corbett B.A.: Salivary cortisol and behavioral response to social evaluative threat in adolescents with autism spectrum disorder: Cortisol Response in adolescents with Autism. Autism Research. 2017; 10: 346-358.

[80] Corbett B.A., Muscatello R.A., Kim A., et al.: Developmental effects in physiological stress in early adolescents with and without autism spectrum disorder. Psychoneuroendocrinology. 2021; 125: 105115.

[81] Ferguson B.J., Marler S., Altstein L.L., et al.: Associations between cytokines, endocrine stress response, and gastrointestinal symptoms in autism spectrum disorder. Brain, Behavior, and Immunity. 2016; 58 : 57-62.

[82] Bishop-Fitzpatrick L., Minshew N.J., Mazefsky C.A., et al.: Perception of Life as Stressful, not Biological Response to Stress, is Associated with Greater Social Disability in Adults with Autism Spectrum Disorder. 2018; 27.

[83] Matherly S.M., Klusek J., Thurman A.J., et al.: Cortisol profiles differentiated in adolescents and young adult males with fragile $X$ syndrome versus autism spectrum disorder. Dev Psychobiol. 2018; 60: 78-89.

[84] Corbett B.A., Muscatello R.A., Baldinger C.: Comparing stress and arousal systems in response to different social contexts in children with ASD. Biological Psychology. 2019; 140: 119-130.

[85] Corbett B.A., Muscatello R.A., Blain S.D.: Impact of Sensory Sensitivity on Physiological Stress Response and Novel Peer Interaction in Children with and without Autism Spectrum Disorder. Front Neurosci. 2016; 10.

[86] Abdulla A., Hegde A.: Salivary Cortisol Levels and its Implication on Behavior In Children with Autism during Dental Treatment. Journal of Clinical Pediatric Dentistry. 2015; 39: 128-132.

[87] Qin D., Rizak J., Feng X., et al.: Prolonged secretion of cortisol as a possible mechanism underlying stress and depressive behaviour. Scientific Reports. 2016; 6: 30187.

[88] Gunnar M.R., Donzella B.: Social regulation of the cortisol levels in early human development. Psychoneuroendocrinology. 2002; 27: 199-220.

[89] Finegood E.D., Wyman C., O'Connor T.G., et al.: Salivary Cortisol and Cognitive Development in Infants From Low-Income Communities. Stress. 2017; 20: 112-121.

[90] Sapolsky R.M., Uno H., Rebert C.S., et al.: Hippocampal damage associated with prolonged glucocorticoid exposure in primates. $J$ Neurosci. 1990; 10: 2897-2902.

[91] Arbel I., Kadar T., Silbermann M., et al.: The effects of long-term corticosterone administration on hippocampal morphology and cognitive performance of middle-aged rats. Brain Research. 1994; 657: 227-235.

[92] de Souza-Talarico J.N., Marin M.-F., Sindi S., et al.: Effects of stress hormones on the brain and cognition: Evidence from normal to pathological aging. Dement Neuropsychol. 2011; 5: 8-16.

[93] Green K.N., Billings L.M., Roozendaal B., et al.: Glucocorticoids increase amyloid-beta and tau pathology in a mouse model of Alzheimer's disease. J Neurosci. 2006; 26: 9047-9056.

[94] Elgh E., Lindqvist Astot A., Fagerlund M., et al.: Cognitive dysfunction, hippocampal atrophy and glucocorticoid feedback in Alzheimer's disease. Biol Psychiatry. 2006; 59: 155-161.

Corresponding author: Magdalena Figlerowicz, Department of Infectious Diseases and Child Neurology, Poznan University of Medical Sciences, Poland; e-mail address: mfiglerowicz@gmail.com 